\title{
Metode Mimicry-Memorization (Mim-Mem Method) dalam Meningkatkan Penguasaan Mufrodat Peserta Didik di Madrasah
}

\author{
Syarifah Aini, dan Mu'allim Wijaya \\ syarifahaini9396@gmail.com \\ prabuwidjaya11@yahoo.com \\ Universitas Nurul Jadid Paiton Probolinggo
}

\begin{abstract}
Abstrak: Penelitian ini menyajikan tentang "Pengaruh Metode Mimicry-Memorization (Mim-Mem Method) Terhadap Penguasaan Mufrodat di Madrasah Aliyah Darul Lughah Wal Karomah". Tujuan digunakannya Metode Mimicry-Memorization (Mim-Mem Method) ini terhadap penguasaan mufrodat di Madrasah Aliyah Darul Lughah Wal Karomah adalah untuk memudahkan pemahaman dan penguasaan mufrodat peserta didik terhadap materi pembelajaran bahasa Arab. Langkah pertama adalah guru melafalkan kosakata lau diikuti oleh siswa. Penelitian dengan metode kuantitatif ini menggunakan jenis penelitian eksperimen (uji coba) dengan jenis data ordinal. Sedangkan metode pengumpulan datanya menggunakan metode tes lisan dengan teknis analisis komparatif (non-parametric) yaitu Mann-Whitney U-test (Uji U). Untuk membuktikan bahwa penelitian ini signifikan atau tidak, peneliti menggunakan data SPSS (Statistical Package for the Social Sciences). Adapun hasil dari data tersebut telah terbukti bahwa ada pengaruh Metode Mimicry Memorization (Mim-Mem Method) terhadap Penguasaan mufrodat di Madrasah Aliyah darul Lughah Wal Karomah. Dengan menggunakan metode tersebut, peserta didik lebih aktif dan lebih efektif dalam mempelajari mata pelajaran bahasa Arab.
\end{abstract}

Kata Kunci : Metode Mimicry Memorization (Mim-Mem Method), Penguasaan Mufrodat.

Abstract: This research presented "influence method of mimicry-
memorization(Mim-Mem Method) toward Mastery of vacabulary in
Madrasah Aliyah Darul Lughah Wal Karomah". The purpose of this
method is to make easily undesrtanding and Master of Vocabulary to
student into arabic language lesson. The first step is the teacher pronounce
the words then repeated by students. This research was experimental.
Whereas the data collection used speaking test method with comparative
analyst technique (Non-Parametric) Mann-Whitney U-test (Uji U). To 
prove this research is significant or not, researchers use SPSS (Statistical Package for the Social Sciences). As for the result Mimicry-Memorization method (Mim-Mem Method) has affected to Vocabulary mastery in Madrasah Aliyah darul Lughah Wal Karomah. By using that method, student will be more active and more effective in learning arabic language lesson.

Keyword: Mimicry Memorization Method, Mastery of Vocabulary

\section{Pendahuluan}

Dalam pembelajaran bahasa Arab, metode mempunyai kedudukan yang sangat signifikan untuk mencapai tujuan. Menurut M. Arifin, metode adalah suatu jalan yang dilalui untuk mencapai suatu tujuan. Jika demikian halnya, maka metode itu harus ada pada setiap proses belajar-mengajar yang dilakukan oleh seorang guru atau tenaga pendidik. ${ }^{1}$

Metode mengajar mempunyai banyak ragam, ada yang bersifat tradisional adapula yang bersifat modern (inovatif). Sebuah pembelajaran bahasa Arab dikatakan berhasil, tergantung bagaimana pendidik (guru) memilih metode yang tepat dalam pembelajarannya. Seorang pendidik sangat perlu melakukan perubahan atau pergantian metode dalam proses belajar-mengajar sejalan dengan perubahan sikap dan minat siswa terhadap materi yang diajarkan. ${ }^{2}$

Beberapa ahli berpendapat mengenai definisi metode pembelajaran, Sanjaya menjelaskan bahwa metode adalah cara yang digunakan untuk mengimplementasikan rencana yang sudah disusun dalam kegiatan nyata agar tujuan yang telah disusum tercapai secara optimal. Sedangkan Muslich memberi pengertian tentang metode pembelajaran sebagai cara untuk melakukan aktivitas yang tersistem dari sebuah lingkungan yang terdiri atas pendidik dan peserta didik untuk saling berinteraksi dalam melakukan suatu kegiatan sehingga proses belajar mengajar berjalan dengan baik. ${ }^{3}$ Dari beberapa definisi di atas dapat disimpulkan bahwa metode pembelajaran merupakan cara yang digunakan dalam proses pembelajaran yang bertujuaan untuk mempermudah pencapaian tujuan pembelajaran yang diharapkan.

${ }^{1}$ M. Arifin, Ilmu Pendidikan Islam (Jakarta: Bumi Aksara, 1996), 61.

2 Sapri, Metode Pembelajaran Bahasa Arab Antara Tradisional dan Modern, Jurnal Pemikiran Alternatif Pendidikan, Insania/Volume.13/Nomor.3

${ }^{3}$ Jamil Suprihatiningrum, Strategi Pembelajaran : Teori dan Aplikasi, (Yogyakarta: Ar-Ruzz Media), 281. 
Dalam Kurikulum Pendidikan Madrasah yang disempurnakan berdasarkan PerMenag 2008 menyangkut bahasa Arab disebutkan bahwa fungsi utama bahasa adalah salah satu alat komunikasi untuk menyampaikan gagasan/pendapat dan perasaan kepada orang lain. Melalui bahasa antar manusia dengan yang lain dapat saling berhubungan (berkomunikasi), saling berbagi pengalaman (bertukar fikiran), saling belajar dari yang lain (intropeksi), dan meningkatkan kemampuan intelektual (intelegensi). ${ }^{4}$

Bahasa arab merupakan salah satu mata pelajaran yang menempati posisi penting dalam dunia pendidikan di Indonesia. Pada jenjang dan program studi tertentu semuanya mengajarkan bahasa Arab sebagai bagian dari mata pelajaran yang harus diajarkan sejajar dengan mata pelajaran yang lain. Lebih-lebih lagi di lembaga pendidikan islam, bahasa merupakan suatu keniscayaan untuk diajarkan kepada peserta didik. $^{5}$

Menurut peraturan menteri Agama RI bahwa mata pelajaran Bahasa Arab adalah salah satu mata pelajaran pokok yang diajarkan pada Madrasah Ibtidaiyah (MI), dimana pelajaran ini dapat memberikan kontribusi positif bagi siswa untuk dapat lebih memahami mata pelajaran lainnya seperti Fiqih, Al-Qur'an Hadits, Aqidah Akhlaq dan Sejarah Kebudayaan Islam yang didalamnya terdapat standar kompetensi agar siswa mengetahui dan memahami kosakata (mufrodat) bahasa Arab terkait materi pada masing-masing mata pelajaran tersebut. Mufrodat merupakan salah satu unsur terpenting dalam bahasa termasuk bahasa Arab, disamping kaidah tata bahasa/ilmu nahwu (sintaksis), ilmu shorrof (morfologi), dan ilmu ashwat (fonetik). Oleh karenanya, mempelajari/memperluas kosakata merupakan prasyarat dan tuntutan yang mendasari seseorang dalam menguasai bahasa Arab tersebut. ${ }^{6}$

Kosakata adalah sekumpulan kata yang membentuk sebuah bahasa. Peran kosakata dalam menguasai empat kemahiran berbahasa sangat diperlukan sebagaimana yang dinyatakan Vallet adalah bahwa kemampuan untuk memahami empat kemahiran berbahasa tersebut sangat bergantung pada penguasaan kosakata

\footnotetext{
${ }^{4}$ Barokatussolihah, Upaya meningkatkan Penguasaan Mufrodat Bahasa Arab Melalui Metode Bernyanyi di Kelas VII A MTsN Donomulyo Kulon Progo, Jurnal Pendidikan Madrasah, Volume 1, Nomor 1, Mei 2016

${ }^{5}$ Abdul Hamid, Pembelajaran Bahasa Arab, Pendekatan, Metode, Strategi dan Media, dan Media, (Yogyakarta: Sukses Offset, 2008), 157.

${ }^{6}$ Zahratun Fajriah, Peningkatan Penguasaan Kosakata bahasa Arab (Mufrodat) Melalui Penggunaan Media Kartu Kata Bergambar, Jurnal Pendidikan Usia Dini, Volume 9/Edisi 1, April 2015.
} 
seseorang. Kekayaan kosakata seseorang secara umum dianggap merupakan gambaran dari tingkat pendidikannya. ${ }^{7}$

Membaca merupakan salah satu kemampuan keterampilan berbahasa yang harus dicapai oleh peserta didik. Keberhasilan peserta didik dalam mengikuti proses belajar-mengajar di sekolah ditentukan oleh penguasaan mereka pada kemampuan membaca. Peserta didik yang tidak dapat membaca akan kesulitan mengikuti kegiatan pembelajaran untuk semua mata pelajaran termasuk pelajaran bahasa Arab. $^{8}$

Oleh karena itu, pengajaran membaca perlu memperoleh perhatian serius, dan wacana membaca tidak boleh hanya dipandang sebagai batu loncatan bagi aktivitas berbicara dan menulis semata. Tujuan pengajaran membaca adalah mengembangkan kemampuan membaca peserta didik. Dengan demikian, tugas guru adalah meyakinkan proses pembelajaran membaca menjadi pengalaman menyenangkan bagi peserta didik. ${ }^{9}$

Proses pembelajaran di Madrasah Aliyah Darul Lughah Wal Karomah sendiri, banyak peserta didik kelas XI yang masih mengalami kesulitan dalam menghafal mufradat. "Kurangnya penguasaan mufradat merupakan masalah yang menjadikan sulitnya mengembangkan materi bahasa Arab pada jenjang berikutnya. Pada kenyataannya dalam menghafalkan mufradat masih banyak peserta didik yang mengalami kesukaran dan kesulitan".

\section{Metode Mimicry-Memorization (Mim-Mem Method)}

Mimicry (yang artinya meniru) dan memorization (yang berarti menghafal). ${ }^{10}$ Memorization berasal dari kata "memori" yang artinya ingat. Memori merupakan suatu yang abstraksi. Ia merujuk pada seperangkat atribut, aktivitas, serta keterampilan, dan bukan mengacu pada satu benda. Keterampilan-keterampilan

\footnotetext{
${ }^{7}$ Sugeng Riyadi, Strategi Pembelajaran Bunyi Dan Mufrodat, Jurnal Ilmu Tarbiyah “At-Tajdid”, Volume 3, Nomor 2, Juli 2014.

${ }^{8}$ Miftakhul Hidayah, dkk, Pengoptimalan Keterampilan Membaca Bahasa Arab Dengan Model Pembelajaran Tutor Sebaya Di Kelas Vii H Mts Negeri Kendal Tabun 2012/2013, Journal of Arabic Learning and Teaching, Volume 2, Nomor 1. 2013.

${ }_{9}$ Miftakhul Hidayah, dkk, Pengoptimalan Keterampilan Membaca Bahasa Arab Dengan Model Pembelajaran Tutor Sebaya Di Kelas Vii H Mts Negeri Kendal Tabun 2012/2013, Journal of Arabic Learning and Teaching, Volume 2, Nomor 1. 2013.

${ }^{10}$ Ulin Nuha, Metodologi Super Efektif Pembelajaran Bahasa Arab, (Yogyakarta: Diva Press, 2012), 215.
} 
ini bisa sangat bervariasi: tidak ada standar tunggal untuk menentukan memori mana yang "baik" dan memori mana yang "buruk". Ian Hunter, ahli psikologi, sebagaimana dikutip oleh Kenneth L.Higbee dan Ricki Linksman, yang berjudul "Memory Superlink Metode Percepatan Belajar" menyatakan bahwa seorang yang menyatakan dirinya memiliki memori yang baik bisa berarti, bahwa ia mampu melakukan salah satu dari berbagai macam aktivitas mengingat kembali pengalaman-pengalaman masa kecilnya, yang sudah bertahun-tahun tidak dikerjakan. $^{11}$

Ada tiga cara pokok untuk mengukur sampai berapa banyak seseorang dapat mengingat. Pertama, kita dapat memintanya untuk menceritakan apa saja yang diingatnya, cara ini disebut dengan recall (mengingat kembali apa yang diingatnya). Kedua, kita dapat memintanya untuk menyebutkan item-item, cara ini sering disebut recognition (mengenali kembali apa yang pernah dipelajarinya). Dan ketiga, kita dapat juga mencoba untuk mengetahui mudah tidaknya ia mempelajari materi tersebut untuk kedua kalinya, cara ini disebut relearning (mempelajari kembali suatu materi untuk kesekian kalinya). ${ }^{12}$ Sedangkan menurut Kelvin Seifert mengemukakan bahwa para guru bisa membuat proses mengingat menjadi lebih baik dalam beberapa cara yaitu dengan menganjurkan pelajaran menyeluruh, atau dengan pembacaan dan metode pembelajaran aktif lainnya. ${ }^{13}$

Pada dasarnya metode mimicry memorization adalah pendekatan lisan dalam pengajaran bahasa, maka proses pembelajaran melibatkan banyak kegiatan latihan lisan/ucapan. Fokus pembelajaran adalah kemampuan menyimak dan berbicara dan menekankan pada aspek menghafal. "Menyimak dan berbicara merupakan kegiatan komunikasi dua arah secara langsung, merupakan komunikasi tatap muka (face to face communication)". ${ }^{14}$

Metode mimicry memorization ini sering dikenal juga sebagai informantdrill method. Karena latihan latihannya dilakukan selain oleh seorang pengajar, juga oleh seorang informan penutur asli (native informan). Kegiatan dalam

${ }^{11}$ Kenneth L. Higbee dan Ricki Linksman, Memory Superlink Metode Percepatan Belajar, (Semarang: Dahara Prize, 2013), 1.

12 Kenneth L. Higbee dan Ricki Linksman, Memory Superlink Metode Percepatan Belajar, hal. 11

${ }^{13}$ Kelvin Seifert, Pedoman Pembelajaran \& Instruksi Pendidikan, (Jogjakarta: Diva Press, 2012), 217.

${ }^{14}$ Henry Guntur Tarigan, Menyimak Sebagai Suatu Keterampilan Berbahasa, (Bandung: Angkasa, 2008), 3. 
metode ini berupa demonstrasi dan latihan/drilling gramatika/struktur kalimat, latihan ucapan dan latihan menggunakan kosakata, dengan mengikuti atau menirukan guru dan informan penutur asli. "Di dalam drilling, native informan bertindak sebagai drilling master, ia mengucapkan beberapa kalimat dan siswa menirukannya beberapa kali sampai hafal". ${ }^{15}$

Dalam istilah arab, metode ini disebut dengan Thoriqatu Al-Simaa' Wa $\mathrm{Al}$ Mubafadzah. Melihat dari namanya, Mimicry-Memorization merupakan sebuah metode pembelajaran yang menekankan pada meniru dan mengingat atau menghafal atau proses pengingatan sesuatu dengan kekuatan memori. ${ }^{16}$

Metode ini disebut Informant Driil Method karena latihan-latihannya yang dilakukan oleh seorang pengajar atau pendidik, kerapkali metode ini juga dilakukan oleh seorang informan penutur asli (native informan). Dalam metode ini, kegiatan belajar berupa demonstrasi dan latihan/drilling gramatika/struktur kalimat, latihan ucapan dan latihan menggunakan kosa kata dengan mengikuti dan menirukan guru. Dalam latihannya, seorang informan penutur asli (native informan) bertindak sebagai drill master. Ia mengucapkan beberapa kosakata (mufrodat) yang kemudian diikuti oleh peserta didik sampai akhirnya ia menjadi hafal. ${ }^{17}$

\section{Penguasaan Mufrodat}

Kosakata yang dikuasai peserta didik sangat erat kaitannya dengan prestasi sekolah secara keseluruhan (Robbins dan Ehri, 1994). Penguasaaan kosakata memiliki fungsi yang sangat penting dalam perkembangan peserta karena peserta didik yang menguasai banyak kosakata, cenderung memiliki rasa percaya diri dan dapat mempengaruhi teman sebayanya untuk bertingkah laku seperti yang diharapkan daripada anak yang memiliki kosakata terbatas (Hamboro, 1995). Bernard (1965) mengatakan bahwa suatu hasil penelitian para eksekutif di bidang bisnis rata rata mempunyai kosakata yang tinggi. ${ }^{18}$

\footnotetext{
${ }^{15}$ Ahmad Muhtadi Anshor, Pengajaran Bahasa Arab Media Dan Metode-Metodenya, (Yogyakarta: TERAS, 2009), 75-76.

16 Bisri Mustofa dan Abdul Hamid, Metode dan Strategi Pembelajaran Bahasa Arab, (Malang: UIN-Malang Press, 2012), 63.

${ }^{17}$ Ismail Suardi Wekke, Model Pembelajaran Bahasa Arab, (Yoyakarta: CV Budi Utama), 2012, 74.

${ }_{18}$ Dwi Agustin Irenaningtyas \& Ratna Wulan, Perbedaan Penguasaan Kosakata Anak Pra-Sekolah, Jurnal Psikologi, Volume 2, Nomor 2, 2004
} 
Menurut pemantauan peneliti saat melakukan observasi, ada beberapa faktor yang menyebabkan kurangnya penguasaan kosakata bahasa Arab (mufradat) siswa yakni: pertama, bahasa Arab merupakan bahasa kedua yang hanya dipelajari siswa ketika berada di sekolah; kedua, monotonnya guru dalam menggunakan metode pembelajaran (konvensional); ketiga, penggunaan media yang kurang variatif, sehingga pembelajaran sering disampaikan secara lisan saja tanpa ada media pendukung yang dapat menarik minat siswa saat guru menjelaskan materi; dan keempat, guru cenderung sebagai pusat pembelajaran (Teacher Centered) dan siswa hanya mendengarkan materi. Metode ceramah dan tanya jawab serta penggunaan buku paket sebagai LKS (Lembar Kerja Siswa) masih sering digunakan ketika menyampaikan materi sehingga siswa cepat merasa jenuh. ${ }^{19}$

Selama ini guru belum bisa menggunakan media secara optimal dalam pembelajaran mufradat dalam bahasa Arab, sehingga siswa kurang begitu antusias dalam menerima materi yang disampaikan oleh guru dan menyebabkan penguasaan mufradat siswa kurang. Hal ini disebabkan karena guru kurang bervariasi dalam menggunakan materi untuk kegiatan pembelajaran. Di samping itu, guru tidak menggunakan media yang optimal sehingga hasil yang dicapai juga kurang memenuhi target yang diharapkan. Usaha memperkaya kosa kata ini tidak hanya lewat pelajaran bahasa, melainkan juga lewat pelajaran lain. Latihan aktif dan terus-menerus itu juga ditekankan oleh Badudu. Pembelajaran bahasa tidak hanya menyiapkan bahan sebanyak-banyaknya, tetapi yang utama memberikan latihan kepada siswa bagaimana menggunakan bahasa yang telah diajarkan itu secara aktif, baik lisan maupun tulisan. ${ }^{20}$

Menurut Sarinah Hardjono, dari aspek bahasa asing yang dianggap paling penting dan harus dikuasai oleh peserta didik ketika melakukan proses belajar mengajar adalah aspek kosakata. ${ }^{21}$ Kosakata merupakan totalitas kata yang digunakan dalam satu bahasa dan penguasaannya dapat diukur dengan menggunakan tes kosakata (Chaplin, 1989). "Kosakata (mufrodat) yang dimiliki peserta didik akan terus meningkat dan berkembang seiring dengan banyaknya pengalaman yang didapat dari

\footnotetext{
${ }^{19}$ Hasil Pengamatan peneliti saat PPL di MA Darul Lughah Wal Karomah

${ }_{20}$ M.Khalilullah, Permainan Teka-Teki Silang Sebagai Media Dalam Pembelajaran Bahasa Arab (Mufrodat) Jurnal Pemikiran Islam, Volume 37, Nomor 1, Januari-Juni 2012

${ }^{21}$ Sartinah Hardjono, Psikologi Belajar Mengajar Bahasa Asing. (Jakarta: Depdikbud, 1988), 71.
} 
lingkungannya maupun proses pembelajaran yang diajarkan di sekolah kepada peserta didik".22

Kosakata merupakan kumpulan kata-kata tertentu yang akan membentuk bahasa. Kata adalah bagian terkecil dari bahasa yang sifatnya bebas. Pengertian ini membedakan antara kata dengan morfem. Morfem adalah unsur terkecil dari bahasa yang tidak bisa dibagi lagi dengan bagian bermakna yang lebih kecil yang maknanya relative stabil. 5 Maka kata terdiri dari morfem-morfem, misalnya kata mu'allim (ملعم) dalam bahasa Arab terdiri dari satu morfem. Sedangkan kata al-mu'allim (المعلم) mempunyai dua morfem yaitu ال ملعم dadapun kata yang mempunyai tiga morfem adalah kata yang terbentuk dari beberapa morfem yang masing-masing morfem mempunyai arti khusus. Misalnya kata al-mu'allimun (المعلمون) yang terdiri dari tiga morfem yaitu ملعم dan ال, dan

Menurut kamus bahasa Indonesia kosa kata adalah pembendaharaan kata.19 Kosa kata adalah semua kata yang terdapat dalam suatu bahasa, kekayaan kata yang dimiliki oleh seorang pembicara atau penulis, kata yang dipakai dalam suatu bidang ilmu pengetahuan. Daftar kata yang disusun seperti kamus disertai penjelasan secara singkat dan praktis. ${ }^{24}$

Faedah penguasaan atau pengetahuan kosakata bagi orang non Arab yang ingin menulis atau mengarang dengan menggunakan bahasa Arab. ${ }^{25}$ Dengan adanya penguasaan bahasa yang memiliki fungsi untuk berkomunikasi dengan baik, maka seorang pembelajar bahasa harus menguasai kosakata, karena kosakata akan banyak membantu peserta didik dalam belajar bahasa asing terutama dalam menguasai

22 Dwi Agustin Irenaningtyas \& Ratna Wulan, Perbedaan Penguasaan Kosakata Anak Pra-Sekolah, Jurnal Psikologi, Volume 2, Nomor 2, 2004

${ }^{23}$ Sugeng Riyadi, Strategi Pembelajaran Bunyi Dan Mufrodat, Jurnal Ilmu Tarbiyah “At-Tajdid”, Volume 3, Nomor 2, Juli 2014

${ }_{24}$ M.Khalilullah, Permainan Teka-Teki Silang Sebagai Media Dalam Pembelajaran Bahasa Arab (Mufrodat) Jurnal Pemikiran Islam, Volume 37, Nomor 1, Januari-Juni 2012

${ }_{25}$ Muh. Ali Khuli, Assalibu Tadris Al-lughoh Al-Arobiyah (Riyad: Muthoba'ah Al-Fazadiq at-Tijariyah, 1982), 99. 
keempat keterampilan berbahasa yaitu, menyimak (istimā’), berbicara (kalam), membaca (qirāàah), dan menulis (kitābah). ${ }^{26}$

"Kualitas keterampilan berbahasa peserta didik sangat bergantung kepada kualitas dan kuantitas kosakata yang dimilikinya, semakin kaya kosa kata yang ia dimiliki, semakin besar pula kemungkinan peserta didik terampil dalam berbahasa". Perlu disadari dan dipahami, bahwa kenaikan kelas para peserta didik di sekolah ditentukan oleh kualitas keterampilan berbahasa mereka. "Kenaikan kelas itu berarti pula merupakan suatu jaminan akan peningkatan kuantitas dan kualitas kosakata mereka dalam bidang studi bahasa Arab yang mereka peroleh sesuai dengan kurikulum". ${ }^{27}$

Dalam pembelajaran kosakata (al-Mufradât) ada baiknya di mulai dengan kosakata dasar yang tidak mudah berubah, seperti halnya istilah kekerabatan, namanama bagian tubuh, kata ganti, kata kerja pokok serta beberapa kosakata lain yang mudah untuk dipelajari. Teknik yang dapat dilakukan yakni dengan berbagai teknik permaianan bahasa, misalnya dengan perbandingan, memperhatikan susunan huruf, penggunaan kamus dan lainnya. Metode yang bisa digunakan dalam pembelajarannya antara lain yaitu metode secara langsung, metode meniru dan menghafal (MimicryMemorization), metode aural-oral approach, metode membaca, metode gramatikatranslation, metode dengan menggunakan media kartu bergambar dan alat peraga. ${ }^{28}$

\section{Metode Penelitian}

Penelitian dengan metode penelitian kuantitatif ini dilaksanakan di kelas XI Madrasah Aliyah Darul Lughah Wal Karomah Sidomukti Kraksaan Probolinggo dengan menggunakan Sample Independent antara kelas XI PK (Program Keagamaan) dan kelas XI IPA dengan rincian kelas XI PK sebagai kelas eksperimen dan kelas XI IPA sebagai kelas kontrol. Adapun jumlah siswi kelas XI PK adalah 28 dan siswi kelas XI IPA adalah 30, yang adapun keseluruhannya berjumlah 58 siswi. Penelitian ini dilakukan selama 1 bulan terhitung sejak tanggal 02 September s/d 11

\footnotetext{
${ }^{26}$ Proyek Pengembangan SISTEM Pendidikan Agama R.I , Pedoman Pengajaran Bahasa Arab pada Perguruan Tinggi Agama/LAIN. (Jakarta: 1974), 171.

27 M.Khalilullah, Permainan Teka-Teki Silang Sebagai Media Dalam Pembelajaran Bahasa Arab (Mufrodat) Jurnal Pemikiran Islam, Volume 37, Nomor 1, Januari-Juni 2012

28 Sugeng Riyadi, Strategi Pembelajaran Bunyi Dan Mufrodat, Jurnal Ilmu Tarbiyah “At-Tajdid”, Volume 3, Nomor 2, Juli 2014
} 
November 2017. Adapun Variabel X (bebas) dalam penelitian ini adalah pengaruh Metode Mimicry-Memorization (Mim-Mem Method) dan Variabel Y (terikat) adalah Penguasaan Mufrodat di Madrasah Aliyah (MA) Darul Lughah Wal Karomah Sidomukti Kraksaan Probolinggo.

Adapun jenis penelitian berdasarkan karakteristik variabel yang digunakan adalah eksperimen (uji coba). Alasan peneliti memilih jenis eksperimen adalah karena metode yang kami ujikan belum pernah diterapkan sebelumnya. Oleh karena itu, melihat kondisi siswi kelas XI yang sangat mimim dalam menguasai mufrodat, peneliti mengambil langkah untuk menggunakan Metode Mimicry-Memorization (Mim-Mem Method).

Jenis data yang digunakan oleh peneliti adalah jenis ordinal. Pada skala ordinal, pendeskripsian data dilakukan pada tabel peringkat. "Bentuk tabelnya adalah tabel tunggal, sedangkan deskripsi data ordinal pada tabel peringkat diisi berdasarkan peringkat tiap data dengan memberi nomor urut pada tiap data sesuai dengan posisinya masing masing", ${ }^{29}$

Dalam penelitian ini, metode pengumpulan datanya menggunakan metode tes lisan. Ketika peneliti ingin mengetahui kemampuan penguasaan mufrodat siswa, langkah pertama yang dilakukan adalah dengan menerapkan metode tes lisan. Kelas XI PK sebagai kelas eksperimen diterapkan metode tes lisan. Kelas XI IPA sebagai kelas kontrol tidak diterapkan metode tersebut, hanya saja peneliti mengetahui kemampuan siswi pada kelas tersebut ketika berselang pembelajaran bahasa Arab saja. Sedangkan jenis penelitian yang digunakan berdasarkan hipotesisnya adalah jenis komparatif. Penelitian komparatif merupakan penelitian yang bersifat membandingkan. Penelitian ini dilakukan untuk membandingkan persamaan dan perbedaan dua atau lebih fakta-fakta dan sifat-sifat objek yang di teliti berdasarkan kerangka pemikiran tertentu. ${ }^{30}$

Teknis analisis yang digunakan dalam penelitian ini adalah Teknik Analisis Komparatif (Non-Parametric) yaitu Mann-Whitney U-test (Uji U). Uji MannWhitney U-test merupakan bagian dari statistik nonparametrik yang digunakan pada

${ }^{29}$ Euis Sartika, pengolahan Data Berskala Ordinal (Ordinal Data Scale Analysis), Jurnal Pengolahan Data Berskala Ordinal, Sigma-Mu Volume. 2 Nomor. 1-Maret 2010

${ }^{30} \mathrm{Ni}$ Kadek Intan Nuariyanti \& Ni Made Adi Erawati, Analisis Komparatif Kinerja Perusahaan, EJurnal Akuntansi Universitas Udayana, Vol.6 No.2 (2014): 274-286 
analisis komparatif untuk menguji hipotesis komparatif dua sampel yang saling independen yang tidak mengasumsikan distribusi normal. ${ }^{31}$

\section{Hasil Penelitian}

Tabel. 1

Form Penilaian Tes lisan Siswa Kelas XI PK \& XI IPA Madrasah Aliyah (MA) Darullughah Wal Karomah

\begin{tabular}{|c|l|c|}
\hline No & \multicolumn{1}{|c|}{ Aspek Yang Dinilai } & Skor Maximal \\
\hline 1 & Pelafalan & 10 \\
\hline 2 & Keberanian & 10 \\
\hline 3 & Pilihan Kata & 10 \\
\hline 4 & Kecepatan Menjawab & 10 \\
\hline \multicolumn{2}{|c|}{ TOTAL } & $\mathbf{4 0}$ \\
\hline
\end{tabular}

Ket :

Nilai Akhir $=\underline{\text { Skor Maximal } \times 100}=100$

40

Berdasarkan Tabel.1 tentang lampiran Form penilaian tes lisan siswa, yang diambil dari pengalaman peneliti ketika menguji tes lisan santri Madrasah Diniyah Pondok Pesantren Darul Lughah Wal Karomah Sidomukti Kraksaan Probolinggo. Adapun aspek-aspek yang dinilai meliputi: pelafalan, keberanian, pilihan kata, dan kecepatan menjawab.

Pertama, Pelafalan dapat merujuk pada : 1) cara kata dari suatu bahasa yang diucapkan, 2) tata cara pengucapan kata. ${ }^{32}$

"Kedua, keberanian adalah suatu sikap untuk berbuat sesuatu dengan tidak terlalu merisaukan beberapa kemungkinan yang buruk. Aristoteles mengatakan bahwa, "The conquering of fear is the beginning of wisdom. Kemampuan menaklukkan rasa takut merupakan awal dari sebuah kebijaksanaan”. Artinya, orang yang mempunyai keberanian yang kuat akan mampu bertindak bijaksana tanpa dibayangi rasa takut yang sebenarnya merupakan halusinasi belaka. Setiap individu yang mempunyai tekad dalam keberanian akan sanggup menghidupkan mimpi-mimpi

${ }^{31}$ Kharisma Prima, Desain Pendidikan \& Analisis Data Kuantitatif, (Bandung: Angkasa, 2008), 72.

32 Informasi mengenai Pronunciation di Wiktionary 
(khayalan-khayalan) dan mengubah kehidupan pribadinya sekaligus kehidupan orangorang disekitarnya menjadi lebih baik. ${ }^{33}$

Ketiga, "menurut KBBI (Kamus Besar Bahasa Indonesia), diksi (pilihan kata) adalah pemilihan kata yang tepat dan selaras dalam penggunaannya untuk mengungkapkan ide atau gagasan sehingga diperoleh efek-efek tertentu seperti yang diharapkan. Diksi juga meliputi pemakaian gaya bahasa dalam sebuah karangan atau percakapan". ${ }^{34}$

Berdasarkan hasil tes lisan yang telah dilakukan di kelas XI PK (Program Keagamaan) sebagai kelas eksperimen adalah berikut: skor tertinggi dengan nilai 100 dicapai oleh 2 siswa, dan skor menengah dengan nilai 95-75 dicapai oleh 22 siswa, sedangkan skor terendah dengan nilai 70-40 dicapai oleh 4 siswa. Adapun hasil tes lisan pada kelas XI IPA sebagai kontrol, skor tertinggi dengan nilai 95-75 dicapai oleh 10 siswa dan skor terendah dengan nilai 70-40 dicapai oleh 20 siswa.

Dari hasil tes lisan tersebut dapat diketahui bahwa kelas yang diberikan metode Mimicry Memorization (Mim-Mem Method) memiliki nilai yang sangat memuaskan dibandingkan kelas yang tidak diterapkan metode tersebut. Namun, dari hasil tes lisan tersebut metode Mimicry Memorization (Mim-Mem Method) belum tentu dinilai berpengaruh terhadap penguasaan mufrodat di MA Darul Lughah Wal Karomah. Dalam penelitian kuantitatif ini, peneliti menggunakan data SPSS (Statistical Package for the Social Sciences) untuk mengetahui ada hubungan (signifikan) atau tidak ada hubungan (tidak signifikan) metode yang digunakan tersebut.

Tabel. 2

Hasil Penelitian Menggunakan SPSS Data Editor

(Statistical Package for the Social Sciences)

\begin{tabular}{|c|c|c|c|c|c|}
\hline \multicolumn{6}{|c|}{ Group Statistics } \\
\hline & Kelas & $\mathrm{N}$ & Mean & Std. Deviation & Std. Error Mean \\
\hline PenguasaanMufrodat I & Kelas EKsperimen & 28 & 79.11 & 13.475 & 2.547 \\
\hline & Kelas Kontrol & 30 & 65.33 & 14.499 & 2.647 \\
\hline
\end{tabular}

${ }^{33}$ Indra, Pengertian dan Ciri-Ciri Keberanian, Jurnal Psikologi, Volume.5 Nomor.2, 2016: 15-

17

34 Diambil dari KBBI (Kamus Besar Bahasa Indonesia) 
Independent Samples Test

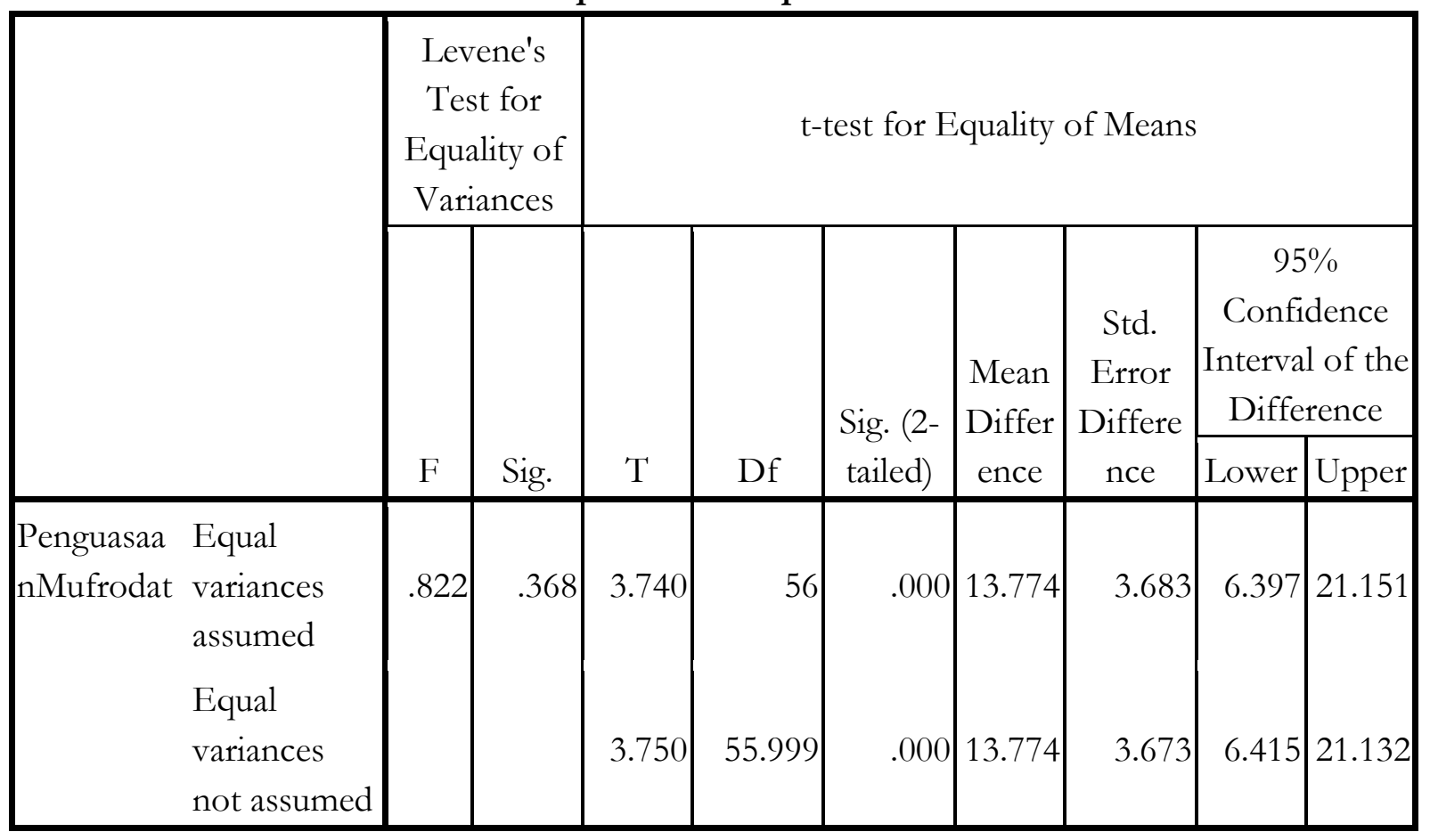

Dalam penelitian kuantitatif, terdapat sebuah istilah hipotesis. Hipotesis berasal dari bahasa Yunani yang mempunyai dua kata yaitu kata "hupo" (sementara) dan "thesis (pernyataan atau teori). Karena hipotesis merupakan pernyataan sementara yang masih lemah kebenarannya, kemudian para ahli menafsirkan arti hipotesis adalah sebagai dugaan terhadap hubungan antara dua variable atau lebih (Kerlinger, 1973:18 dan Tuckman,1982:5). ${ }^{35}$

"Sudjana (1992:219) juga mengartikan hipotesis sebagai dugaan sementara mengenai suatu hal yang dibuat untuk menjelaskan sesuatu yang sering dituntut untuk dilakukan pengecekan". Atas dasar defenisi diatas, sehingga dapat diartikan bahwa hipotesis adalah jawaban atau dugaan sementara yang harus diuji lagi kebenarannya. ${ }^{36}$

${ }^{35}$ Harnovinsah, Metodologi Penelitian Jenis-Jenis Hipotesis,(Bandung: Angkasa, 2012), modul 6, 1.
${ }^{36}$ Harnovinsah, Metodologi Penelitian Jenis-Jenis Hipotesis,(Bandung: Angkasa, 2012), modul 6, 1. 
Hipotesis ada 2, yaitu: $\mathrm{H}_{\mathrm{a}}$ (Hipotesis Aktif/Alternatif) dan $\mathrm{H}_{0}$ (Hipotesis Nihil/Nol). Dalam hipotesis $\mathrm{H}_{a}$ yang berarti dalam penelitian ini ada Pengaruh Metode Mimicry Memorization (Mim-Mem Method) terhadap Penguasaan Mufrodat di Madrasah Aliyah (MA) Darul Lughah Wal Karomah. Sedangkan $\mathrm{H}_{0}$ yang berarti tidak ada Pengaruh Metode Mimicry Memorization (Mim-Mem Method) terhadap Penguasaan Mufrodat di Madrasah Aliyah (MA) Darul Lughah Wal Karomah.

Berdasarkan hasil analisis menggunakan SPSS Data Editor (Statistical Package for the Social Sciences) diatas, telah diketahui bahwa terdapat nilai hitung/Sig. (2tailed) sebesar $=0,000$. Hal ini jika dibandingkan dengan nilai kritik $(0,05)$, maka diketahui nilai hitung lebih kecil dari nilai kritik yang berarti signifikan (berhubungan) : $0,000<0,05=$ yang berarti Signifikan.

Variabel Metode Mimicry Memorization (Mim-Mem Method) jika dikorelasikan dengan variabel Penguasaan Mufrodat dihasilkan nilai Sig. $=0,000$ (ada korelasi yang signifikan), artinya Metode Mimicry Memorization (Mim-Mem Method) berkorelasi dengan Penguasaan Mufrodat di MA (Madrasah Aliyah) Darul Lughah Wal Karomah, atau bisa dikatakan bahwa Metode Mimicry Memorization (MimMem Method) dapat meningkatkan Penguasaan Mufrodat di MA (Madrasah Aliyah) Darul Lughah Wal Karomah.

Adapun besar pengaruh dari penerapan Metode Mimicry Memorization (Mim-Mem Method) pada kelas XI PK (Program Keagamaan) adalah sebesar 13,774. Nilai 13,774 dilihat dari nilai Mean Difference pada hasil analisis menggunakan data SPSS. pada hasil analisis diatas juga dihasilkan bahwa pada kelas eksperimen terdapat nilai rata-rata sebesar79,11 dan pada kelas kontrol terdapat nilai rata-rata sebesar 65,33, yang mana jika nilai rata-rata pada kelas kelas eksperimen dikurangi nilai ratarata pada kelas kontrol (79,11-65,33) akan dihasilkan 13,774. Oleh karena itu, sebab nilai 13,774 inilah kelas eksperimen dikatakan kelas yang berhasil atau kelas yang mendapatkan pengaruh lebih dari penerapan Metode Mimicry Memorization (MimMem Method).

\section{Pembahasan}

Menurut Sarinah Hardjono, dari aspek bahasa asing yang dianggap paling penting dan harus dikuasai oleh peserta didik ketika melakukan proses belajar 
mengajar adalah aspek kosakata. ${ }^{37}$ Kosakata merupakan totalitas kata yang digunakan dalam satu bahasa dan penguasaannya dapat diukur dengan menggunakan tes kosakata (Chaplin, 1989).

Faedah penguasaan atau pengetahuan kosakata bagi orang non Arab yang ingin menulis atau mengarang dengan menggunakan bahasa Arab. ${ }^{38}$ Dengan adanya penguasaan bahasa yang memiliki fungsi untuk berkomunikasi dengan baik, maka seorang pembelajar bahasa harus menguasai kosakata, karena kosakata akan banyak membantu peserta didik dalam belajar bahasa asing terutama dalam menguasai keempat keterampilan berbahasa yaitu, menyimak (istimā'), berbicara(muhādtsa), membaca (qirā’ah), dan menulis (kitābah). ${ }^{39}$

Setiap keterampilan tersebut erat sekali hubungannya dengan keterampilan lainnya. Adapun salah satu aspek yang menentukan keberhasilan pengajaran bahasa Arab khususnya dalam pengajaran kosakata ini adalah aspek metodologi. Sebab metodelah yang menentukan isi dan cara mengajar. ${ }^{40}$ Dalam metodologi pembelajaran terdapat dua aspek yang paling menonjol yang harus difahami, yaitu: metode mengajar dan media pembelajaran sebagai alat bantu ketika mengajar. Dari bermacam-macam metode pembelajaran bahasa Arab, ternyata metode Mimicry Memorization (Mim-Mem Method) yang efektif dan efisien untuk mengajarkan kosakata dalam bahasa Arab. ${ }^{41}$

"Penguasaan kosakata peserta didik di Indonesia pada umumnya sangatlah minim (masih rendah), hal ini diungkapkan oleh Hamboro (1995) berdasarkan pengamatan yang dilakukan ketika menguji inteligensi anak (peserta didik) khususnya dalam subtes mufrodat (kosakata)"."Pada subtes ini peserta didik umumnya mengalami kesulitan dalam memberikan respon walaupun hasil tes inteligensi menunjukkan tingkat inteligensi peserta didik tersebut berada pada tingkat rata-rata atau bahkan di atas rata rata". "Menurut Rusyana (dalam Kaligis, 1996) berdasarkan

\footnotetext{
${ }^{37}$ Sartinah Hardjono, Psikologi Belajar Mengajar Bahasa Asing. (Jakarta: Depdikbud, 1988), 71.

38 Muh. Ali Khuli, Assalibu Tadris Al-lughoh Al-Arobiyah (Riyad: Muthoba'ah Al-Fazadiq at-Tijariyah, 1982), 99.

39 Proyek Pengembangan SISTEM Pendidikan Agama R.I, Pedoman Pengajaran Bahasa Arab padaPerguruan Tinggi Agama/IAIN. (Jakarta: 1974), 171.

${ }^{40}$ Muljianto Sumardi, Pengajaran Bahasa Asing. Sebuah Tinjanan dari Segi Metodologis. (Jakarta: 1974).

41 Siti Hasnah, Pembelajaran Kosakata(Mufradāt) Bahasa Arab Melalui Media Gambar Untuk Meningkatkan Minat Belajar Mahasiswa Pada Jurusan Pai Fakultas Tarbiyah Iain Palu, Istiqra':Jurnal penelitian Ilmiah, Vol.3, No.1, Juni 2015
} 
penelitian yang dilakukannya pada tahun 1981 terhadap siswa kelas X dan XI di Jawa Barat, kemampuan berbahasa khususnya dalam segi penguasaan mufodat (kosakata) peserta didik dapat dikatakan sangat memprihatinkan". "Demikian juga dengan hasil penelitian Silahiddin tahun 1981 terhadap siswa kelas XI di Sumatera Selatan, menunjukkan minimnya penguasaan mufodat (kosakata) yang dimiliki siswa (dalam Kaligis, 1996)". Ki Supriyoko dari Taman Siswa Yogyakarta menemukan sekitar satu setengah persen dari 2000 anak sekolah dasar di Ujung Pandang tidak lancar membaca, sehingga sudah lulus sekolah dasar pun tetap belum lancar membaca, hal tersebut dikarenakan penguasaan mufodat (kosakata) yang sangat minim (Buletin Anak, 1999). Rendahnya penguasaan kosakata (mufrodat) akan berpengaruh pada kemampuan berbahasa peserta didik dan akan berakibat pula pada kemampuan komunikasi dalam sehari-harinya, padahal kemampuan ini sangat diperlukan untuk dijadikan bekal bagi peserta didik di Indonesia untuk menyongsong masa depan yang penuh dengan tantangan dan persaingan. ${ }^{42}$

Dalam penyampaian pesan melalui bahasa, pemilihan kosakata yang tepat merupakan hal penting untuk mengungkapkan makna yang dikehendaki. Pemahaman yang tepat terhadap pesan yang disampaikan melalui bahasa, banyak ditentukan oleh pemahaman yang tepat terhadap kosakata yang digunakan didalamnya. Pembelajaran kosakata berkaitan dengan penguasaan makna kata-kata, di samping kemampuan menggunakannya pada konteks yang tepat dan tempat yang tepat pula. ${ }^{43}$

Dalil tentang pentingnya mempelajari bahasa Arab telah tercantum dalam AlQuran surat Fushshilat ayat 3:

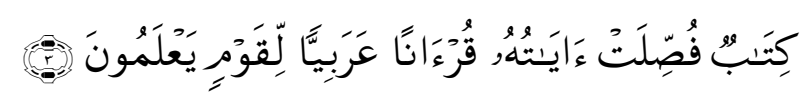

Artinya: "Kitab yang dijelaskan ayat-ayatnya, yakni bacaan dalam bahasa Arab, untuk kaum yang mengetahui.” (QS. Fushshilat: 3)

Dari paparan tersebut jelas bahwa Islam menganjurkan umatnya untuk mempelajari bahasa Arab. Bahasa Arab dan Al-Quran bagaikan dua sisi mata uang yang tidak dapat dipisahkan antara satu dengan yang lain. Mempelajari

42 Dwi Agustin Irenaningtyas \& Ratna Wulan, Perbedaan Penguasaan Kosakata Anak Pra-Sekolah, Jurnal Psikologi, Volume 2, Nomor 2, 2004

43 Abdul Wahab Rosyidi,Media Pembelajaran Bahasa Arab, (Malang: UIN-Malang Press,2009), 54. 
bahasa Arab adalah syarat wajib untuk menguasai isi Al-Quran. Dan mempelajari bahasa Al-Quran berarti mempelajari bahasa Arab. Dengan demikian peranan bahasa Arab di samping sebagai alat komunikasi sesama manusia juga komunikasi manusia beriman kepada Allah, yang terwujud dalam bentuk shalat,doa, dan sebagainya.

Langkah pertama untuk mudah belajar bahasa Arab adalah dengan mempelajari kosa kata bahasa Arab atau sering disebut dengan mufradat. "Mufradat atau kosa kata (Inggris: vocabulary) adalah himpunan kata atau khazanah kata yang diketahui oleh seseorang (peserta didik) atau merupakan bagian terpenting dari suatu bahasa tertentu". Kosa kata seseorang didefinisikan sebagai himpunan semua kata kata yang dipahami atau dimengerti oleh orang tersebut dan kemungkinan akan digunakannya untuk menyusun kalimat baru untuk berkomunikasi. Secara umum, kekayaan kosakata peserta didik merupakan gambaran atau acuan dari intelegensia atau tingkat pendidikannya. ${ }^{44}$ Menurut Ahmad Djanan Asifuddin, pembelajaran kosa kata (al-mufradat) yaitu proses penyampaian bahan pembelajaran yang berupa kata atau perbendaharaan kata sebagai unsur dalam pembelajaran bahasa Arab. ${ }^{45}$

Menurut pemantauan peneliti saat melakukan observasi, ada beberapa faktor yang menyebabkan kurangnya penguasaan kosakata bahasa Arab (mufradat) siswa yakni: pertama, bahasa Arab merupakan bahasa kedua yang hanya dipelajari siswa ketika berada di sekolah; kedua, monotonnya guru dalam menggunakan metode pembelajaran (konvensional); ketiga, penggunaan media yang kurang variatif, sehingga pembelajaran sering disampaikan secara lisan saja tanpa ada media pendukung yang dapat menarik minat siswa saat guru menjelaskan materi; dan keempat, guru cenderung sebagai pusat pembelajaran (Teacher Centered) dan siswa hanya mendengarkan materi. Metode ceramah dan tanya jawab serta penggunaan buku paket sebagai LKS (Lembar Kerja Siswa) masih sering digunakan ketika menyampaikan materi sehingga siswa cepat merasa jenuh. ${ }^{46}$

\footnotetext{
44 Azhar Arsyad, Bahasa Arab dan Metode Pengajarannya, (Yogyakarta: Pustaka Pelajar, 2004), ${ }^{45}$ Baharuddin, dkk, Teori Belajar dan Pembelajaran, (Jogjakarta: Ar-Ruzz Media, 2008, 14.

${ }^{46}$ Hasil Pengamatan peneliti saat PPL di MA Darul Lughah Wal Karomah
} 
"Kualitas keterampilan berbahasa peserta didik sangat bergantung kepada kualitas dan kuantitas kosakata yang dimilikinya, semakin kaya kosa kata yang ia dimiliki, semakin besar pula kemungkinan peserta didik terampil dalam berbahasa". Perlu disadari dan dipahami, bahwa kenaikan kelas para peserta didik di sekolah ditentukan oleh kualitas keterampilan berbahasa mereka. "Kenaikan kelas itu berarti pula merupakan suatu jaminan akan peningkatan kuantitas dan kualitas kosakata mereka dalam bidang studi bahasa Arab yang mereka peroleh sesuai dengan kurikulum". ${ }^{47}$

\section{Kesimpulan}

Tanggapan siswa kelas XI PK (Program Keagamaan) Madrasah Aliyah Darul Lughah Wal Karomah selaku kelas eksperimen yang telah diterapkan Metode Mimicry Memorization (Mim-Mem Method) terhadap penguasaan mufrodat diinterpretasikan berpengaruh baik karena skor tertinggi dengan nilai 100 dicapai oleh 2 siswa, dan skor menengah dengan nilai 95-75 dicapai oleh 22 siswa, sedangkan skor terendah dengan nilai 70-40 dicapai oleh 4 siswa.

Berdasarkan pengolahan dan analisis data dengan dibantu program SPSS diperoleh nilai hitung/Sig. (2-tailed) sebesar $=0,000$. Hal ini jika dibandingkan dengan nilai kritik $(0,05)$, maka diketahui nilai hitung lebih kecil dari nilai kritik yang berarti signifikan (berhubungan) : 0,000 > 0,05 = yang berarti Signifikan. Artinya metode mimicry memorization (Mim-Mem Method) dengan penguasaan mufrodat siswa memiliki pengaruh yang signifikan, dengan demikian dapat disimpulkan bahwa terdapat pengaruh metode mimicry memorization (Mim-Mem Method) terhadap penguasaan mufrodat di Madrasah Aliyah (MA) darul Lughah Wal Karomah. Setelah dikorelasikan menunjukkan interprestasi tingkat reliabilitas tinggi besarnya pengaruh metode mimicry memorization (Mim-Mem Method) terhadap penguasaan mufrodat adalah nilai hitung/Sig. (2-tailed) sebesar $=0,000$.

Adapun besar pengaruh dari penerapan Metode Mimicry Memorization (Mim-Mem Method) pada kelas XI PK (Program Keagamaan) adalah sebesar 13,774. Nilai 13,774 dilihat dari nilai Mean Difference pada hasil analisis menggunakan data SPSS. pada hasil analisis diatas juga dihasilkan bahwa pada kelas eksperimen terdapat

${ }^{47}$ M.Khalilullah, Permainan Teka-Teki Silang Sebagai Media Dalam Pembelajaran Bahasa Arab (Mufrodat) Jurnal Pemikiran Islam, Volume 37, Nomor 1, Januari-Juni 2012 
nilai rata-rata sebesar79,11 dan pada kelas kontrol terdapat nilai rata-rata sebesar 65,33, yang mana jika nilai rata-rata pada kelas kelas eksperimen dikurangi nilai ratarata pada kelas kontrol (79,11-65,33) akan dihasilkan 13,774. Oleh karena itu, sebab nilai 13,774 inilah kelas eksperimen dikatakan kelas yang berhasil atau kelas yang mendapatkan pengaruh lebih dari penerapan Metode Mimicry Memorization (MimMem Method).

Adapun besar pengaruh dari penerapan Metode Mimicry Memorization (Mim-Mem Method) pada kelas XI PK (Program Keagamaan) adalah sebesar 13,774. Nilai 13,774 dilihat dari nilai Mean Difference pada hasil analisis menggunakan data SPSS. pada hasil analisis diatas juga dihasilkan bahwa pada kelas eksperimen terdapat nilai rata-rata sebesar79,11 dan pada kelas kontrol terdapat nilai rata-rata sebesar 65,33, yang mana jika nilai rata-rata pada kelas kelas eksperimen dikurangi nilai ratarata pada kelas kontrol (79,11-65,33) akan dihasilkan 13,774. Oleh karena itu, sebab nilai 13,774 inilah kelas eksperimen dikatakan kelas yang berhasil atau kelas yang mendapatkan pengaruh lebih dari penerapan Metode Mimicry Memorization (MimMem Method). 


\section{Daftar Pustaka}

Abdul Hamid, Pembelajaran Bahasa Arab, Pendekatan, Metode, Strategi dan Media, dan Media, (Yogyakarta: Sukses Offset, 2008)

Abdul Wahab Rosyidi,Media Pembelajaran Bahasa Arab, (Malang: UIN-Malang Press,2009)

Ahmad Muhtadi Anshor, Pengajaran Babasa Arab Media Dan Metode-Metodenya, (Yogyakarta: TERAS, 2009)

Azhar Arsyad, Bahasa Arab dan Metode Pengajarannya, (Yogyakarta: Pustaka Pelajar, 2004)

Baharuddin, dkk, Teori Belajar dan Pembelajaran, Jogjakarta: Ar-Ruzz Media, 2008

Barokatussolihah, Upaya meningkatkan Penguasaan Mufrodat Bahasa Arab Melalui Metode Bernyanyi di Kelas VII A MTsN Donomulyo Kulon Progo, Jurnal Pendidikan Madrasah, Volume 1, Nomor 1, Mei 2016

Bisri Mustofa dan Abdul Hamid, Metode dan Strategi Pembelajaran Babasa Arab, (Malang: UIN-Malang Press, 2012)

Dwi Agustin Irenaningtyas \& Ratna Wulan, Perbedaan Penguasaan Kosakata Anak PraSekolah, Jurnal Psikologi, Volume 2, Nomor 2, 2004

Indra, Pengertian dan Ciri-Ciri Keberanian, Jurnal Psikologi, Volume.5 Nomor.2, 2016: 15-17

Informasi mengenai Pronunciation di Wiktionary

Ismail Suardi Wekke, Model Pembelajaran Bahasa Arab, (Yoyakarta: CV Budi Utama), 2012

Jamil Suprihatiningrum, Strategi Pembelajaran: Teori dan Aplikasi, (Yogyakarta: Ar-Ruzz Media)

Kelvin Seifert, Pedoman Pembelajaran \& Instruksi Pendidikan, (Jogjakarta: Diva Press, 2012)

Kenneth L. Higbee dan Ricki Linksman, Memory Superlink Metode Percepatan Belajar, (Semarang: Dahara Prize, 2013)

Kharisma Prima, Desain Pendidikan \& Analisis Data Kuantitatif, (Bandung: Angkasa, 2008)

M. Arifin, Ilmu Pendidikan Islam (Jakarta: Bumi Aksara, 1996) 
M.Khalilullah, Permainan Teka-Teki Silang Sebagai Media Dalam Pembelajaran Bahasa Arab (Mufrodat) Jurnal Pemikiran Islam, Volume 37, Nomor 1, Januari-Juni 2012

Miftakhul Hidayah, dkk, Pengoptimalan Keterampilan Membaca Bahasa Arab Dengan Model Pembelajaran Tutor Sebaya Di Kelas Vii H Mts Negeri Kendal Tabun 2012/2013, Journal of Arabic Learning and Teaching, Volume 2, Nomor 1. 2013

Muh. Ali Khuli, Assalibu Tadris Al-lughoh Al-Arobiyah (Riyad: Muthoba'ah AlFazadiq at-Tijariyah, 1982)

Muljianto Sumardi, Pengajaran Bahasa Asing. Sebuah Tinjanan dari Segi Metodologis. (Jakarta: 1974).

Ni Kadek Intan Nuariyanti \& Ni Made Adi Erawati, Analisis Komparatif Kinerja Perusahaan, E-Jurnal Akuntansi Universitas Udayana, Vol.6 No.2 (2014): 274-286

Proyek Pengembangan SISTEM Pendidikan Agama R.I , Pedoman Pengajaran Bahasa Arab pada Perguruan Tinggi Agama/ IAIN. (Jakarta: 1974)

Sapri, Metode Pembelajaran Bahasa Arab Antara Tradisional dan Modern, Jurnal Pemikiran Alternatif Pendidikan, Insania/Volume.13/Nomor.3

Sartinah Hardjono, Psikologi Belajar Mengajar Bahasa Asing. (Jakarta: Depdikbud, 1988)

Siti Hasnah, Pembelajaran Kosakata(Mufradāt) Bahasa Arab Melalui Media Gambar Untuk Meningkatkan Minat Belajar Mahasiswa Pada Jurusan Pai Fakultas Tarbiyah Iain Palu, Istiqra':Jurnal penelitian Ilmiah, Vol.3, No.1, Juni 2015

Sugeng Riyadi, Strategi Pembelajaran Bunyi Dan Mufrodat, Jurnal Ilmu Tarbiyah "AtTajdid”, Volume 3, Nomor 2, Juli 2014

Ulin Nuha, Metodologi Super Efektif Pembelajaran Bahasa Arab, (Yogyakarta: Diva Press, 2012)

Zahratun Fajriah, Peningkatan Penguasaan Kosakata bahasa Arab (Mufrodat) Melalui Penggunaan Media Kartu Kata Bergambar, Jurnal Pendidikan Usia Dini, Volume 9/Edisi 1, April 2015 